\title{
Violence in the community: study of community mental health teams
}

\author{
Nigel Eastwood and Robert Pugh
}

\begin{abstract}
The experience of violence towards members of community mental health teams was explored using a questionnaire. Reeponse rates were $97 \%$. The number of staff experiencing various types of violence was greater than in previous studies. Staff were generally well-informed about the theoretical issues and had sensible attitudes towards the risk of violence. Appropriate training was found to be lacking and other Department of Heatth and Social Security recommendations were not being followed. These included information about whereabouts of staff, and mechanisms for communication. We recommend that training issues are addressed locally and that safe theory should be transtated into safe practice which is regularty monitored.
\end{abstract}

A number of studies have looked at violence towards health workers who work with psychiatric patients. These have considered a variety of settings, including in-patient units (Whittington, 1994), general practice (Hobbs, 1991; British Medical Association Medical Services Committee, 1993) and social services (Bute, 1994). Apart from studies which have looked at small numbers of mental health nurses in the community (Royal College of Nursing, 1994; Whitefield \& Shelley, 1991) no research has focused specifcally on violence towards members of community mental health teams (CMHTs).

Clear advice for safe practice during work in the community was issued by the Department of Health and Social Security in 1988 (DHSS, 1988), however it does not seem to have had a high profile. These guidelines are summarised in the Appendix. Advice on developing and implementing a policy on personal safety was commissioned by the Suzy Lamplugh Trust (Bibby, 1995).

This study set out to explore the following issues:

(a) What experience of violence do members of CMHTs have.

(b) What attitudes do such workers have about violence. (c) To what extent do they take practical steps to protect themselves against potential incidents, with reference to the DHSS guidelines.

\section{The study}

Procedure

All health workers in CMHTs employed by Norfolk Mental Health Care NHS Trust were sent a questionnaire by post.

\section{Subjects}

Recipients comprised community psychiatric nurses (CPNs), community learning disability nurses (CLDNs), occupational therapists and psychiatrists (consultants, senior registrars, registrars and senior house officers).

\section{Measures}

The questionnaire comprised three main parts

Number of violent incidents in previous year. A retrospective count of incidents was made by the recipient. There are difficulties in defining violence (Poyner \& Warne, 1986), so a range of different measures of violence were included in this study. These included three categories of violence ('threat of violence', 'verbal abuse' and 'violence to others'). in addition to a three-point scale of physical violence, developed by Fottrell (1980).

Attitudes towards violence. Nine questions dealt with such issues as perceived degree of risk, confidence about dealing with incidents, and the need to 'play down' incidents.

Clinical practice. Thirteen items, based on the DHSS guidelines (see Appendix), asked about measures taken to minimalise the risks of being the subject of violence. 


\section{Findings}

\section{Response}

One hundred and forty-three questionnaires were sent out to all members of the multidisciplinary CMHTs; 139 (97\%) were returned.

Violence in previous year. Exposure to violence was common: $68.4 \%$ of CPNs had experienced 'verbal abuse': $31.2 \%$ of CLDNs reported violence to others'. Ten per cent of respondents had experienced physical assault, and $2.9 \%$ had suffered minor or major physical injuries.

Attitudes towards violence. All respondents were aware of a degree of risk, with most describing it as 'moderate' or 'slight'; $49.6 \%$ of staff knew a colleague who had been involved in a violent incident. There was a good awareness of how staff behaviour can have an effect on violence, with $92 \%$ of respondents feeling confident about their ability to cope with incidents. Twenty-seven per cent of staff felt at least a 'moderate' pressure to 'play down' violent incidents. There was no significant difference between professions.

Clinical practice. Experience of relevant training in managing violence was poor (36.7\%), particularly among doctors (26.5\%). Only $25.9 \%$ of respondents had a sound idea of their units' safety policy. Table 1 summarises the replies relating to clinical procedure.

It was not common practice for staff to preview their day's work for potential violence, particularly among doctors. Respondents' whereabouts in the community were poorly monitored, with only $17.1 \%$ of CPNs leaving details of their travels at least 'most of the time'. Only a small number of staff regularly made arrangements to be contacted if they did not return to base on time. Apart from $1.3 \%$ of CPNs, no one regularly carried violent incident forms with them. Overall, 9.4\% of staff owned functioning personal alarms, but only $2.9 \%$ carried them at least most of the time'. Forty-two and a half per cent of respondents carried out-of-hours telephone numbers but a minority of staff carried mobile telephones with them.

\section{Comment}

All degrees of violence were experienced by more staff than have been reported in previous community studies although comparisons were limited by the different mixes of professions in each study and the variety of definitions used for violence.

Our results suggest that staff working in the community are aware of both the theoretical

Table 1. Responses to questions about clinical procedure

\begin{tabular}{|c|c|c|c|c|c|}
\hline & \multicolumn{5}{|c|}{ Respondents (\%) } \\
\hline & $\begin{array}{l}\text { Community } \\
\text { psychiatric } \\
\text { nurse }\end{array}$ & $\begin{array}{l}\text { Community } \\
\text { leaming } \\
\text { clisoblitity nurse }\end{array}$ & $\begin{array}{l}\text { Occupational } \\
\text { theraplat }\end{array}$ & Doctor & Tolat \\
\hline $\begin{array}{l}\text { How often do you preview your day's work for } \\
\text { areas of risk? ("at least most of time') }\end{array}$ & 61 & 43.8 & 33.3 & 18.2 & 46.4 \\
\hline $\begin{array}{l}\text { Would you take appropriate action if you } \\
\text { identified such an area (e.g. escort, police)? } \\
\text { ('definitely') }\end{array}$ & 75 & 75 & 61.5 & 18.2 & 69.8 \\
\hline $\begin{array}{l}\text { How often do you leave a detailed record of } \\
\text { your itinerary and expected departure/arrival } \\
\text { times? ("at least most of time") }\end{array}$ & 17.1 & 62.5 & 46.2 & 55.9 & 34.5 \\
\hline $\begin{array}{l}\text { How often do you tell appropriate people about } \\
\text { any changes in plan (e.g. colleagues, } \\
\text { managers)? ('at least most of time') }\end{array}$ & 34.2 & 62.5 & 38.5 & 61.8 & 44.6 \\
\hline $\begin{array}{l}\text { How often do you arrange to be contacted if } \\
\text { your return is overdue? ('at least most of time') }\end{array}$ & 9.2 & 0 & 0 & 8.8 & 7.2 \\
\hline $\begin{array}{l}\text { How often do you carry forms to record and } \\
\text { report incidents? ('at least most of time') }\end{array}$ & 1.3 & 0 & 0 & 0 & 1.4 \\
\hline Do you have a personal alarm which works? ('yes") & ) 10.5 & 6.3 & 0 & 11.8 & 9.4 \\
\hline $\begin{array}{l}\text { How often do you carry out-of-hours telephone } \\
\text { numbers etc. to summon help? ('at least most } \\
\text { of time') }\end{array}$ & 48.6 & 37.5 & 15.4 & 41.2 & 42.5 \\
\hline $\begin{array}{l}\text { How often do you carry a means of } \\
\text { identification? ('at least most of time') }\end{array}$ & 97.3 & 100 & 92.3 & 85.3 & 94.2 \\
\hline $\begin{array}{l}\text { How often do you carry a mobile 'phone? ('at } \\
\text { least most of time') }\end{array}$ & 18.7 & 12.5 & 23.1 & 29.4 & 21 \\
\hline
\end{tabular}


aspects of risk, and their application to their own situations. A significant number of workers felt a degree of pressure to 'play down' violent incidents.

However, although the majority of staff felt competent to manage violent incidents, many staff (63.3-73.5\%) had never received any appropriate training. This shows little improvement on the findings of the Health Services Advisory Committee (1987) in which $88 \%$ of the 3000 respondents had not received any training in violence; these included staff from nonpsychiatric settings. The Royal College of Nursing study (1994) found that $32.5 \%$ of the 40 CPNs had never been trained in managing violence.

Other recommendations for safe practice were not regularly followed by our respondents. The most concerning areas involved communication and whereabouts of staff. The Trust is currently carrying out a specific initiative of managing violence and the training of staff.

\section{Recommendations}

This study shows that although staff were aware of most issues about violence, they had not changed their behaviour and precautions were rarely taken. Staff require training in the management of violence and standards need to be set for both the structure and process of safer practice. These should be monitored by regular audit.

\section{Appendix DHSS Guidelines (1988) for staff working in the community}

Have you:

1. had all the relevant training about violence to staff?

2. a sound grasp of your unit's safety policy for visitors?

3. a clear idea about the area into which you are going?

4. carefully previewed today's cases?

5. asked to 'double up', take an escort or use a taxd if unsure?

6. made appointment(s)?

7. left your itinerary and expected departure/ arrival times?

8. told colleagues, manager, etc. about possible changes of plan?

9. arranged for contact if your return is overdue?
Do you carry:

10. forms to record and report 'incidents'?

11. a personal alarm or radio? Does it work? Is it handy?

12. a bag/briefcase, wear an outer uniform or car stickers that suggest you have money or drugs with you? Is this wise where you are going today/tonight?

13. out-of-hours telephone numbers, etc. to summon help?

Can you:

14. be certain your attitudes, body language, etc. won't cause trouble?

15. defuse potential problems and manage aggression?

\section{References}

Bibby, P. (1995) Personal Safety for Health Care Workers. London: Ashgate Publishing.

Brttish Medical association medical Services Committee (1993) Confidential Survey of Iondon GPs. Final Report London: Electoral Reform Ballot Services.

BUTE. S. (1994) Violence to social irorkers. In Violence and Heulth Care Professionals (eci. T. Wykes). pp. 45-71. London: Chapman and Hall.

DEPARTMENT OF HEALTH AND SOCIAL SECURTY (1988) Violence to Staff: Report of the DHSS Advisory Committee on Violence to Health. London: HMSO.

FOTTRELL. E. (1980) A study of violent behaviour among patients in psychlatric hospitals. British Journal of Psychiatry, 136, 216-221.

Health Services Advisory Committee (1987) Violence to Staff in the Health Services. London: HMSO.

HовBS, F. D. R. (1991) Violence in general practice: a survey of general practitioners' views. British Medical Journal 302. 329-332.

POYNER, B. \& WARNE, C. (1986) Violence to Staff: A Basis for Assessment and Prevention. The Tavistock Institute of Human Relations. Health and Safety Executtve. London: HMSO.

ROYAL COLLEGE OF NURSING (1994) Violence and Community Nursing Staff. London: Royal College of Nursing.

WHITFIELD, W. \& SHELLEY, P. (1991) Violence and the CPN: a survey. Community Psychiatric Nursing Journal, 1, 1318.

WhITTINGTON. R. (1994) Violence in in-patient units. In Violence and Health Care Professionals (ed. T. Wykes), pp. 23-43. London: Chapman and Hall.

Nigel Eastwood, Consultant Psychiatrist. Cornwall Healthcare Trust St Lawrence's Hospital, Bodmin, Cornwall; and *Robert Pugh, Consultant in Rehabilitation Psychiatry, Norfolk Mental Health Care NHS Trust, Hellesdon Hospital, Drayton High Road, Norwich NR6 5BE

*Correspondence 